In a large proportion of the essays I have written, the same subject of plane position has had to be con-idered and described I am, therefore, somewhat seriously interested in "pposing as well the disuse of the word "prsition," which no one can misunderstand, as the use of the words "aspect," "slope," "tilt," \&c, in a sense not at present assigned (nor properly assignable) to them. RICHD. A. PROCTOR

\section{Sea-water Aquaria}

I HAVE read with much gusto your article upon the Crystal Palace Aquarium. I am induced by it to put forward a caution wilh regard to the construction of rock-work in tanks.

Several weeks ago, casually looking over a heap of Bangor slaty rock, on the road bordering the Brighton Aquarium works, and being used for the rock-work of tanks, my atteniton was attracted by some bright green patches upon some of the srones, which appeared to me to be carbonate of coppex, but was probably silicate. Looking further at one with a lens, I imagined that I could also distinguish particles of peacock ore. On attempting to purloin a specimen, I was very properly stopped from so crimina! an act by the Cerberts in charge. I wrote to the chairman of the company, stating that, not having examined the stone, I might be only contributing a mare's nest to their znological collection, but that if it contained much copper the fish would be in danger. I understand that upon rectipt of myletter some rock was sent up to Dr. Percy, whose report, I am told, was to the effect that there was much sulphide of comper, and that the pretty green rock was therefore unfit for tank rock-work.

I think this will serve as a caution to the constructors of aquaria to examine all material which is to be in contact with water most carefully before u*ing it. There are so many minerals which would be deleserions that I strongly advise an analysis and report in the case of every untried rock. The accident of my passing a heap of stones has saved the company, with which I am not in the least connected except as a fervent well-wisher, from a large expenditure and a serious scrape.

Allow me to ask those who are accustomed to the management of tanks, whether hydraulic pressure upon a small and strong one would be likely to assist in maintaining life in any of the deep-sea organisms, and whether it would be useful to make rectsses for those loving darkness, with the axes opposite the plate glass side, so that a bull's-eye lantern could occasionally throw light upon their actions and mode of life?

Brighton, Oct. 2 I

Marshall Hall

\section{ON HOMOPLASTIC AGREEMENTS IN}

\section{PLANTS}

$A T$ the recent meeting of the British Association I A pointed out in a short communication the difference that existed between mimicry in animals and what has been spoken of under that name amongst plants. The distinction was sufficiently obvious, and must have occurred to everyone who had given the matter any consideration, but my object was to try to raise a discussion upon the whole subject as exhibited in plants.

I fancy it is hardly sufficiently understood how commonly this agreement of facies occur in plants widely differing in other respects. I will give a few illustrations of it. Humboldt remarks ("Views of Nature," p. 35I) : "In all European colonies the inhabitants have been led by resemblances of physiognomy (habitus, facies) to apply the names of European forms to certain tropical plants, which bear wholly different flowers and fruits from the genera to which these designations originally referred. Everywhere in both hemispheres the northern settler has believed he could recognise alders, poplars, apple, and olive trees, being misled for the most part by the form of the leaves and the direction of the branches." Nor has the popular eye alone been deceived by these resemblances. Schleiden states ("The Plant,"p. 255) that Australia has in common with Europe a very common plant, the daisy, yet Dr. Hooker has pointed out (Flora of Tasmania, pl. 47) that the plant intended by Schleiden is the very similar but distinct Brachycoma decipiens Hook. fil. Again, true flowering plants bi longing to the very curious family Podostemacece have been figured as liverworts and other cryptogamic plants (Berkeley, Intr. to Crypt. Bot., p. 5). Many other instances of similar errors might be given."

Since I read my paper, I have met with an essay by Schouw, in which he enumerates facts of the same kind. "There is still," he says ("Earth, Plants, and Man,"p. 6r), "another kind of repetition which I might call habitual repetition, or denominate mimicry, if this expression was not at variance with the subjection to law which exists throughout nature, but to comprehend which our powers are oiten insufficient." After various illustrations he proceeds:- "In the genus Mutisia we have the remarkable sight of a compositous flower, with the tendrils of a leguminous plant." (This by an accidental coincidence was one of the instances which I, myself, used at Edinburgh.) "In Begonia fuchsioides the leaves are similar to a Fuchsia, and very different from the other forms of leaf among the begonias, and the colour of the blossom likewise reminds us of the fuchsias. We have another most striking example in certain Brazilian plants, which although possessed of perfectly developed flowers and fruits, mimic, as it were, in their leaves and stems, groups of plants of much lower rank." (He is alluding to the Podosiemacece mentioned above.) "Lacis fucoides resembles certain seaweeds so much, that it might be mis. taken for one by a person who did not see the flowers. Mniopsis scuturiginum strikingly resembles a fungermannia."

I suggested that when a plant put on the characteristic facies of a distinct natural family, it might conveniently be spoken of as a pseudomorph, having in view an obvious analogy in the case of minerals. I do not, however, now think on further consideration, that this term, although convenient, includes all the cases. In small natural fami. lies it is not always easy to recognise any general habit or facies at all, and in the case of plants belonging to different families where this is the case, but having a similar habit, it would be purely arbitrary to fix the pseudomorphism on any of them. Again all the individuals of distinct groups of plants might have a similar habit, and the same remark would apply. The difficulty is, however, got over by speaking of the plants in these cases as isomorntic.

My friend, Mr. E. R. Lankester, has pointed out to me that agreements of this kind may all come under what he has termed homoplasy (Ann. and Mag. of Natural History, July I 870). This is the explanation he gives of this expression :-

"When identical or nearly similar forces, or environments, act on two or more parts of an organism which are exactly or nearly alike, the resulting modifications of the various parts will be exactly or nearly alike. Further, if, instead of similar parts in the same organism, we suppose the same forces to act on parts in two organisms, which parts are exactly or nearly alike and sometimes homogenetic, the resulting correspondences called forth in the several parts in the two organisms will be nearly or exactly alike. I propose to call this kind of agreement homo plasis or homoplasy. The fore legs have a homoplastic agreement with the hind legs, the four extremities being, in their simplest form (e.g. Proteus, which must have had ancestors with quite rudimentary hind legs), very closely similar in structure and function. ... Homoplasy includes all cases of close resemblance of form not traceable to homogeny."

The resemblances, therefore, above described between the vegetative organ of plants with no close generic relations, may be described as homoplastic. The diffictilty

* Perhaps one of the most striking is the Natal cycad Stangerio paradoxa baving been published and described by Kunze as a species of Lomaria, a genus of Ferns. 